\title{
IS COLLABORATION THE FUTURE FOR MUSEUM ARCHAEOLOGY?
}

\section{Mikael Nordström}

Jönköpings läns museum

Box 2133, 55002 Jönköping, Sweden

mikael.nordstrom@jkpglm.se

\section{BACKGROUND}

What is museum archaeology? The simple answer is archaeology performed by archaeologists engaged at a museum, that is, everything from leading and implementing excavations (mainly in the form of contract archaeology) to taking care of artefacts or making the archaeological results public. What should be expected from a museum archaeologist? The person ought to have knowledge about the archaeological collections at the museum and have a good hunch about the regional cultural heritage and ancient monuments. Why do we perform museum archaeology? The answer lies most likely in the old museum slogan to 'collect, preserve and exhibit' the cultural heritage. This was more or less the reason for creating local heritage societies and museums at the end of the Igth century and the beginning of the 20 th century.

To facilitate the government in its work of guarding and protecting the nationwide cultural heritage, the demand for local presence arose, which resulted in county representatives for Riksantikvarieämbetet (the National Heritage Board). The representative was also head of Länsmuseet (the county museum). 
Länsmuseer have had the responsibility for regional cultural heritage matters since the I930s. A breaking point took place in 1976 when that role was transferred from the museums to Länsstyrelsen (the County Administrative Board). At the beginning of 2 Ist century a more profound change was launched when full competition and a multiplicity of companies was favoured over the importance of regional knowledge usually held within the museums.

The role of Länsstyrelsen presupposes of course a knowledge about the cultural heritage, but their knowledge about museum collections varies to a great deal.

The question is what role does museum archaeology play? Where do the Länsmuseerna fit in this new assignment?

\section{THE CHALLENGE}

The former special position of Länsmuseerna in working with the regional cultural heritage has eroded and within contract archaeology completely disappeared. The system for contract archaeology no longer makes exceptions for county museums with the justification that their unique knowledge of the regional cultural heritage should be appreciated, as was the case earlier (for instance SOU 2005:80 Uppdragsarkeologi i tiden 2005:80). Länsstyrelsen is obliged to see that there is a multiply of archaeological companies, and to purchase all excavations with a cost of more than 20 price base amounts (KRFS 20I5:I Riksantikvarieämbetets föreskrifter och allmänna råd om uppdragsarkeologi 2015).

The big losers in a system like this are companies who are restricted to work within a limited area, which means, above all, Länsmuseerna. Not only do they lose market shares, one must also be aware that contract archaeology, from time to time, has produced a considerable economic contribution the museums, which the museums to some extent have made themselves dependent upon for the maintenance of nonarchaeological activities (Länsmuseernas och motsvarande museers kulturmiljöarbete 2015:32ff.).

In times of economic decline this dependency could have serious consequences for the whole of the museum, not only the part dealing with contract archaeology. The county museums have great economic challenges (Länsmuseernas situation: En konsultrapport 20I6).

Is the solution to dismantle contract archaeology at Länsmuseerna to minimize the economic risk? Or to try to uphold the business as long as possible, slowly but surely losing competence and financial means? 
Contract archaeology at regional museums will be ousted if there isn't a very good and continuous market with limited competition.

The loss of competence because of reduced financial means at Länsmuseerna is not a problem confined to Sweden. That issue was discussed in November 2016 at Museums Association Conference and Exhibition in Glasgow (Glasgow Conference Guide 7-9 November 2016). A speech by a member of The Society for Museum Archaeology in a session titled 'Subject specialist networks: what next?' showed that less than half of the British museums 'with archaeological collections employ a curator with specialist archaeological expertise' (quotation from a Powerpoint presentation; see also Boyle et al. 20I6).

\section{CONSEQUENCES}

But even if Länsmuseerna no longer are an obvious performer and partner within contract archaeology, their mission in the work with the regional cultural heritage still remains (Prop. 2012/13:96 Kulturmiliöns maingfald 2013:63; see also Länsmuseernas och motsvarande museers kulturmiliöarbete 2015): 'The County Administrative Board shall, within the framework of its responsibility for cultural environmental work in the county, cooperate with the cultural environment authorities in the county, especially the county museums and corresponding museums' (SFS I988:I 88 Kulturmiljöförordning, Allmänna bestämmelser $\$ 2$ ).

That is also something that is highlighted in the government culture budget for 2018 (Prop. 20I7/I8:I Budgetpropositionen för 2018 20I8:I20). The government's bill states emphatically that the government grants which are distributed through the county councils also include the museums' work with cultural heritage (Prop. 2016/I7:I I6 Kulturarvspolitik 20I7:I48). The problem is that reduced public financing forces the museums to choose between disciplines such as ethnology, art, museum education, cultural heritage and archaeology. The public grants are not being increased enough to match the costs.

The author of this article is at present discussing next year's budget where resources for cultural heritage and archaeology have to stand back in favour of other investments and activities. In 2018 we will be down to the lowest level for the past 25-30 years regarding means for publicly financed museum archaeology. An obvious risk is that Länsmuseerna also are forced to refuse to store archaeological finds, because the expertise and resources to handle them is missing. This is a current issue at several museums today and also a question of great importance to Länsmuseet in Jönköping. 
Several museums have decided not to take part in the contract archaeology market, partly with the argument that publicly financed museums should not compete with private companies, partly because the economic risk is too high. Decreasing market shares in contract archaeology give an uncertain economic basis which causes Länsmuseerna to consider dismantling contract archaeology (Westerberg 2017:26; Ökad konkurrens på det uppdragsarkeologiska området: Vissa ändringar $i$ kulturminneslagen 2011:46f.).

\section{POSSIBILITIES}

If contract archaeology within the framework of Länsmuseerna is to survive, contract archaeology must have the opportunity to act outside the county borders in order to handle fluctuations in the market as well as to keep the necessary archaeological expertise - preferably through collaboration with other museums. This collaboration must be formalized in some way. How to accomplish this is the big question. In the worst case the old understanding that regional museums do not compete with each other has to be abandoned.

Within Museiarkeologiska branschorganisationen M-ark (The Museum Archaeological Trade Association) forms for collaboration between contract archaeologists at different Länsmuseer have developed. This has been absolutely necessary for the museums to be competitive in a tendering procedure.

The progress of publicly financed archaeology is even more uncertain because archaeology is only one of several disciplines that the museums are expected to maintain. What should be the priorities in times of reduced grants? An important future issue for Länsmuseerna will therefore be to discuss forms for collaboration. We must explore new ways to help each other to maintain expertise, not least within the archaeological field.

\section{REFERENCES}

Budgetpropositionen för 20I8. 20I7. Regeringens proposition 20I7/I8:I. Utgiftsområde I7. Kultur, medier, trossamfund och fritid. Stockholm: Regeringen.

Kulturarvspolitik. 2017. Regeringens proposition 20I6/I7:I I6. Stockholm: Riksdagen.

Kulturmiljöförordning (SFS ı988:Iı88). Kulturdepartementet. Utfärdad I988-ı I-IO. Ändring införd t.o.m. SFS 2017:56I.

Kulturmiliöns mangfald. 2013. Regeringens proposition 2012/I3:96. Stockholm: Regeringen. 
Länsmuseernas situation: En konsultrapport. 20I6. Visby: Riksutställningar.

Länsmuseernas och motsvarande museers kulturmiljöarbete: Kartläggning och redovisning av förutsättningarna för samverkan och verksambetsutveckling på regional nivå. 2015. Stockholm: Riksantikvarieämbetet.

Ökadkonkurrenspådetuppdragsarkeologiska området: Vissaändringarikulturminneslagen. 20I I. Stockholm: Kulturdepartementet.

Westerberg, J. O. 20I7. Bevarade kulturmiliöer och utvecklat sambälle:Rapport. Stockholm: Kulturförvaltningen, Stockholms läns landsting.

\section{Internet resource}

Boyle, G., Booth, N. \& Rawden. A. 2016. Collecting Archaeology (England). Report Year I: November 20I6. Society for Museum Archaeology/Historic England. [online] Available at: <http://socmusarch.org.uk/socmusarch/gailmark/wordpress/ wp-content/uploads/20I6/o7/HE-SURVEY-20I6-FINAL.pdf $>$ [Accessed 6 October 2017].

Glasgow Conference Guide 7-9 November 2016. The Museums Association. [online] Available at: <https://view.pagetiger.com/glasgow20r6/guide> [Accessed 20 December 20I7]. 